\title{
Nd:YAG laser in art works restoration
}

\author{
T. Flores ${ }^{(*)}$, L. Ponce ${ }^{(*)}$, B. Moreno ${ }^{(* *)}$, M. Arronte ${ }^{(*)}$, \\ M. Fernándaz ${ }^{(* *)}$ y C. García ${ }^{(* *)}$
}

\begin{abstract}
Laser cleaning in works of art has a number of advantages over traditional techniques of restoration. In this article, the technique used and the physical mechanisms that explain the process of ablation of pollutants are described. The results obtained in the cleaning of statues of marble and alabaster are exposed as well as oil-painting restoration. In this last specific case, the Nd:YAG laser is used with successful results.
\end{abstract}

Keywords: Laser. Ablation. Cleaning. Restoration. Evaporation

\section{Limpieza de obras de arte con láser de Nd:YAG}

\begin{abstract}
Resumen La limpieza de obras de arte por láser presenta una serie de ventajas sobre técnicas tradicionales de restauración. En el presente trabajo se describen la técnica empleada y los mecanismos físicos que explican el proceso de ablación de contaminantes. Se reportan los resultados alcanzados en la limpieza de estatuas de mármol y alabastro, así como en la restauración de pintura al óleo. En este último caso, se emplea por primera vez el láser de Nd:YAG con resultados ventajosos.
\end{abstract}

Palabras clave: Láser. Ablación. Limpieza. Restauración. Evaporación.

\section{INTRODUCTION}

The earliest record of the use of laser in art conservation is to be found at the beginning of the decade of the 70's (1). From the preliminary research works of Asmus (2) up to the present date, the laser cleaning have been made in marble and limestone, textiles, tapestries, leather, pottery, colored glass, bronze and aluminum, etc. In all cases, the cleaning consists of removing the superficial encrustations with the minimum damage for the base material (3).

\section{ADVANTAGES OF LASER CLEANING}

In the abrasive, chemical and manual-mechanical techniques of cleaning, environmental pollution and variation in the superficial profile of art work are provoked (3). Compared with other techniques, and based on the versatility, accurate control and minimum environmental damage of laser; it permits

(*) IMRE. Univ. de la Habana. (Cuba). (lasertec@ ffuh.fmq. uh.edu.cu)

(**) Centro de Restauración, Conservación y Museología CENCREM (Cuba).

(***) Universidad Autónoma Metropolitana UAM-Iztapalapa, México a selective elimination of dirtiness without mechanical contact with the surface, preservation of superficial relief and avoid continued action after the cleaning has finished.

\subsection{Main physical mechanisms}

In previous research works (2) the mechanisms of cleaning are related to the characteristic of laser. Watkings et al. (3) put forward the mechanisms that involves selective evaporation, photo and thermal decomposition and ablation by shock wave in QSwitch regime. In painting, laser excimer has been used (4 and 5), and this article gives a report on the application of Nd:YAG laser by using an ultraviolet wavelength. Radiation power, pulse length and wavelength make Nd:YAG laser the most used, specially in the cleaning of all kinds of stones. Table I shows the lasers used in this work and their more important features, as well as the right concrete application in art cleaning. The samples were treated and analyzed by means of techniques as optical microscopy with digitalization of image (NEOPHOT21 microscope) and color pictures. Table II resumes the lasers, samples and results of the cleaning. 
TABLE I.- Nd:YAG lasers used for the cleaning in our work

TABLA I.- Láseres de Nd:YAG utilizados para la limpieza

\begin{tabular}{|l|l|l|}
\hline & \multicolumn{1}{|c|}{ Characteristics } & \multicolumn{1}{c|}{ Application in clening } \\
\hline GOS-1001 & $E=1000 \mathrm{~J}, d=4 \mathrm{~cm}, T=1 \mathrm{~ms}$ & Marble, limestone, alabaster \\
\hline PL-ART & $E=0,25 \mathrm{~J}, f=10 \mathrm{~Hz}, T=10 \mathrm{~ns}$ & Marble \\
\hline YAG-LTI-501 & $P=16 \mathrm{~W}, f=5, \mathrm{Khz}, T=30 \mathrm{~ns}$ & Alabaster \\
\hline Lumonics HY 1200 & $\lambda=1064,532,355,266 \mathrm{~nm}, \mathrm{f}=10 \mathrm{~Hz}$ & Painting \\
\hline
\end{tabular}

\section{CARRARA MARBLE AND ALABASTER}

The laser used possesses a high pulse power which permits to clean big areas with one pulse. When using free generation $(1 \mathrm{~ms})$ the cleaning mechanism would be the selective vaporization of encrustations. For the case of Carrara Marble, the absorvance was for the pollutant layer $=0.6$. This strong difference of absorption $(\beta)$ between the pollutant and the surface for $1,064 \mathrm{~nm}(0.2$ and 0.6$)$ enables to make the selective evaporation of the dirtiness without damaging the surface (3). In the case of alabaster, two pieces were treated: a dirty ornamental vase also covered with a thick layer of soot; and a Dante bust. The high energy and diameter of the laser beam used permitted to clean the bust in a $4 \mathrm{~h}$ work session.

\subsection{Oil paintings}

Fotakis (4) reported the laser excimer cleaning of oil-paintings. In this case, two experiments were made. Removal of the grime layer at the back of an old portrait and removal of the varnish layer and dirtiness over the painting. The first was made with an anonymous 18th century portrait of the Mexican Guadalupe Virgin. The first step to take in the process of restoration is to eliminate the grime layer which covers the back of the cloth and reclothing again. The cleaning was very well done without any affection at a speed higher than that of the traditional methods and without using chemicals, thus contributing to the preservation of the portrait (Fig. 1).

The second experiment consists of cleaning over the portrait and it was made with a Mexican paint

TABLE II.- Summary of results

TABLA II.-Resumen de resultados

\begin{tabular}{|l|l|l|l|l|}
\hline \multicolumn{1}{|c|}{ Samples } & \multicolumn{1}{|c|}{$\begin{array}{c}\text { Types of } \\
\text { encrustations }\end{array}$} & \multicolumn{1}{|c|}{ Laser } & $E\left(\mathrm{~J} / \mathrm{cm}^{2}\right)$ & \multicolumn{1}{|c|}{ Results } \\
\hline Carrara marble & $\begin{array}{l}\text { Encrustation due to } \\
\text { pollution, stains of } \\
\text { bronze oxide. }\end{array}$ & GOS-1001 & $20-265.5$ & $\begin{array}{l}\text { Residues of melted metal and } \\
\text { the center is left completely } \\
\text { clean. }\end{array}$ \\
\hline Carrara marble & $\begin{array}{l}\text { Enscrustation due to } \\
\text { pollution }\end{array}$ & GOS-1001 & 20 & $\begin{array}{l}\text { Total elimination of } \\
\text { encrustations. }\end{array}$ \\
\hline $\begin{array}{l}\text { Alabaster } \\
\text { (Bust of Dante) }\end{array}$ & $\begin{array}{l}\text { Enscrustations due to } \\
\text { pollution and soot }\end{array}$ & GOS-1001 & 20 & $\begin{array}{l}\text { Enscrustations are eliminated. } \\
\text { The sample was moistened } \\
\text { with water film. }\end{array}$ \\
\hline Alabaster (vase) & $\begin{array}{l}\text { Enscrustations due to } \\
\text { pollution and soot }\end{array}$ & GOS-1001 & 10.16 & $\begin{array}{l}\text { Enscrustations are eliminated. } \\
\text { The sample was moistened } \\
\text { with water film. }\end{array}$ \\
\hline Alabaster (vase) & $\begin{array}{l}\text { Enscrustations due to } \\
\text { pollution and soot }\end{array}$ & LTI-501 & - & $\begin{array}{l}\text { The pollutant layer is } \\
\text { completely eliminated but } \\
\text { with excessive loss of layer) }\end{array}$ \\
\hline Oil-painting & $\begin{array}{l}\text { Layer of dirtiness } \\
\text { over the cloth }\end{array}$ & Lumonics & 1.42 & $\begin{array}{l}\text { The layer of dirtiness of the } \\
\text { cloth is eliminated. }\end{array}$ \\
\hline Oil-painting & $\begin{array}{l}\text { Layer of varnish over } \\
\text { the painting }\end{array}$ & Lumonics & 1.4 & $\begin{array}{l}\text { Varnish and dirtiness are } \\
\text { eliminated. }\end{array}$ \\
\hline
\end{tabular}




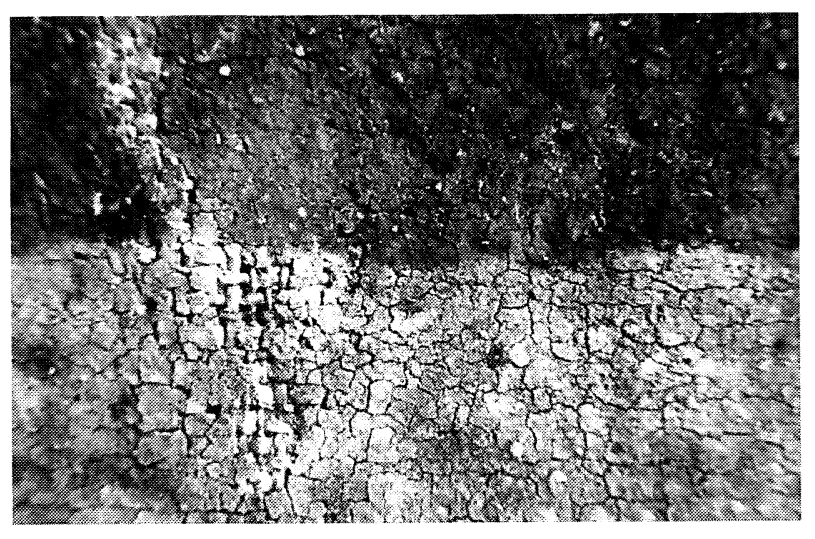

FIG. 1.- Back of the linen cloth during the cleaning process. Detail of the treated zone.

FIG. 1.- Detalle del reverso de un lienzo sometido a limpieza láser.

from the beginning of the century. The most appropriate regime was achieved with $266 \mathrm{~nm}$, pulse energy $100 \mathrm{~mJ}$. For this wavelength, the cleaning process relies on non-thermal photoablation of contaminants due the strong absorption. Changing the energy density, the amount of material removing can be controlled. However, the generalization of $\mathrm{Nd}$ laser cleaning of paints may lead to complications similar to the difficulties with excimer lasers (6).

\section{SPECTROPHOTOMETRY REFLECTANCE OF SURFACE}

In all measured range $(500-2500 \mathrm{~nm})$ the reflectance of treated surface was higher than the reflectance of untreated area (Fig. 2). These results confirm that the cleaning process can be controlled by real time feedback reflectance measurements (5).

\section{CONCLUSIONS}

- The cleaning of Carrara marble due to environmental pollution and of alabaster due to soot pollution was made successfully by means of a $\mathrm{Nd}$ laser.

- A layer of dirtiness from the back cloth of a painting using $\mathrm{Nd}$ laser in Q-Switch mode was removed.

- The cleaning varnish layer and dirtiness adhered to the painting can be removed by means of

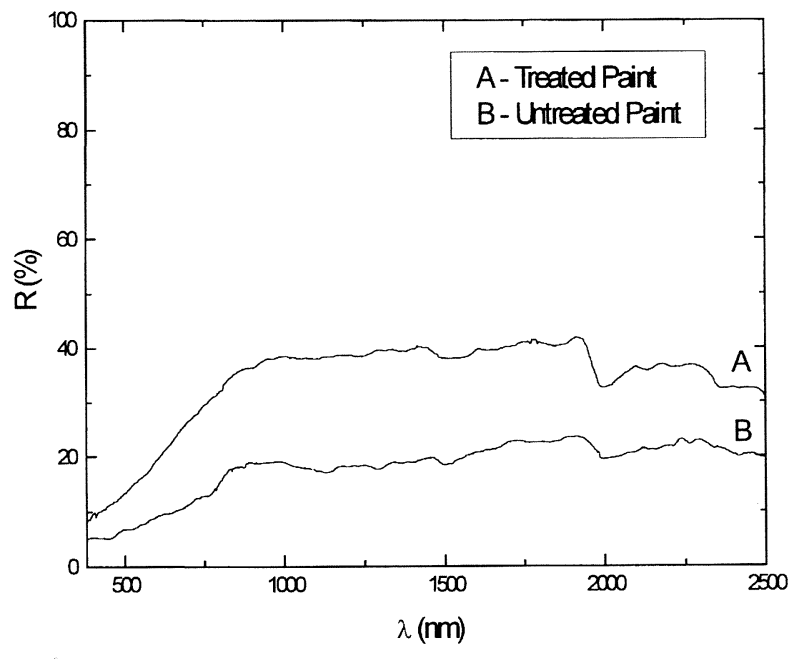

FIG. 2.- Reflectance spectra of the linen cloth.

FIG. 2.-Reflectancia espectral del lienzo.

doing the treatment with wavelength $266 \mathrm{~nm}$ without damaging the art work.

- Laser cleaning of art works permits to improve the process of restoration once it decreases the damage to the art work and it increases the speed of the process.

\section{Acknowledgment}

This research work has been supported by CYTED (Ripromal Network) and CONACYT, México (project 400200-5-4225E).

\section{REFERENCES}

(1) Asmus, J.F. et. al. Studies in Conservation, 18 (2), 1973.

(2) Asmus, J.F. Int. Sci. Rev. 12, 1987: 171.

(3) Watkins, K.G. et al. Proc NATO ASI. Laser processing: Surface Treatment and Film Deposition. Sesimbra (Portugal) July 3-16, 1994.

(4) Fotakis, C. Optics and Phonics News. 6, 30, 1995.

(5) FotAkis, C. et. al. (Paper delivered at the 23rd Annual Meeting of the American Institute for Conservation, St. Paul (MN., USA) Jun. 10, 1995). Postprints of papers presented at the Paintings Specialty Group, 1995 AIC Meeting, 1996.

(6) Hontzopoulos, E., Fotakis, C. and Doulgeridis, M. SPIE. Vol. 1810 Gas Flow and Chemical Lasers, 148, 1992. 